\title{
PENGARUH LIMBAH KULIT KOPI (Coffea $s p$ ) PENGOLAHAN SEDERHANA DENGAN LEVEL SUBSTITUSI SEBAGIAN JAGUNG TERHADAP PERSENTASE ORGAN DALAM AYAM PEDAGING
}

\author{
Melisa Palapa, L.M.S. Tangkau, P.R.R.I. Montong*, Z. Poli
}

Fakultas Peternakan Universitas Sam Ratulangi Manado, 95115

\begin{abstract}
ABSTRAK
Penelitian ini bertujuan untuk mengetahui bagaimana pengaruh limbah kulit kopi pengolahan sederhana dengan level substitusi sebagian jagung terhadap persentase organ dalam ayam pedaging. Penelitian ini dilaksanakan di kandang Fakultas Peternakan Universitas Sam Ratulangi Manado selama 35 hari. Ayam pedaging yang digunakan dalam penelitian ini sebanyak 144 ekor DOC strain CP 707 tanpa membedakan jenis kelamin (unsex). Kandang yang digunakan yaitu kandang baterai berjumlah 36 unit dan setiap unit kandang ditempati 4 ekor ayam. Rancangan penelitian yang digunakan yaitu rancangan acak lengkap (RAL) pola faktorial $3 \times 4$ dengan masing-masing perlakuan 3 ulangan. Faktor A terdiri atas tiga macam perlakuan yaitu A1 adalah kulit kopi yang dijemur, A2 adalah kulit kopi yang direndam, dan A3 kulit kopi yang direbus sedangkan faktor B yaitu level substitusi kulit kopi terhadap jagung dimana B0 (0\% kulit kopi dalam ransum), B1 (substitusi 25\% kulit kopi), B2 (substitusi 50\% kulit kopi) dan B3(subsitusi 75\% kulit kopi). Berdasarkan hasil analisis keragaman (Anova) menunjukan bahwa interaksi antara kulit kopi jemur, rendam, rebus dan level subtitusi memberikan pengaruh yang tidak berbeda nyata $(\mathrm{P}>0.05)$ terhadap persentase hati, jantung, dan gizzard. Hasil yang sama juga ditunjukan oleh metode pengolahan kulit kopi (A) yang artinya,
\end{abstract}

*Korespondensi (correspondingAuthor)

Email: richard_montong@unsrat.ac.id jemur, rendam dan rebus tidak memberikan pengaruh sedangkan level substitusi menunjukan hasil berbeda nyata $(\mathrm{P}<0.05)$ terhadap persentase bobot hati. Rataan persentase organ dalam berturut-turut yaitu, hati 1,38\%-1,86\%, jantung 0,29\%-0,72\%, gizzard 1,60\%-2,77\%. Dari hasil penelitian dapat disimpulkan bahwa penggunaan tepung limbah kulit kopi pada semua metode pengolahan yang terbaik hanya sampai pada $25 \%$ menggantikan sebagian jagung terhadap persentase organ dalam ayam pedaging.

Kata kunci: Ayam broiler, kulit kopi, organ dalam hati, jantung, gizzard

\section{ABSTRACT}

EEFCT OF COFFEE HUSK WASTE PRODUCT TREATED BY SIMPLE PROCESSING SUBSTITUTED WITH PART OF CORN IN RATION ON PERCENTAGE OF BROILER INTERNAL ORGAN.

This study was conducted to evaluate the use of coffee husk waste product treated by simple processing substituted with part of corn in ration on percentage of broiler internal organ. Study was applied at Faculty of Animal Science, Sam Ratulangi University during 35 days. Total of 144 day old chick unsexed broilers, strain of CP 707, involving 36 experimental units of battery pens were used in this study. Each unit of pen was filled 4 birds under completely randomized design on factorial patter of $3 \times 4$. Factor $A$ was focused on three processing treatments including coffee husk heated under sun light (A1), coffee 
husk immersed in the water (A2), and coffee husk boiled under water (A3). Factor $B$ was focused on four treatments of substitution levels including ration containing corn without coffee husk substitution (B0), ration containing corn substituted with $25 \%$ coffee husk (B1), ration containing corn substituted with $50 \%$ coffee husk(B2), ration containing corn substituted with $75 \%$ coffee husk (B3). Analysis of variance showed that interaction of processing treatments did not affect significantly on the percentages of lung, heart and gizzard. This study indicated that simple processing of coffee husk were not affected the percentages of broiler internal organ. The substitution levels significantly affected percentage of internal organ. Percentages of lung, heart and gizzard were $1.38-1.86 \%, 0.31-0.72 \%$ and $1.6-2.77 \%$, respectively. This study showed that utilization of coffee husk waste product by above simple processing could substitute part of corn in ration of $25 \%$ producing high percentage of broiler internal organ.

Keywords: Broiler, Coffee husk by product, broiler internal organ

\section{PENDAHULUAN}

Ayam pedaging disebut juga dengan ayam broiler yang merupakan salah satu ternak yang dibutuhkan oleh masyarakat Indonesia dalam pemenuhan kebutuhan protein hewani. Pada umumnya ternak unggas, khususnya ayam pedaging termasuk golongan yang memiliki pertumbuhan yang sangat cepat. Keseimbangan zat-zat nutrisi terutama imbangan energi dan protein sangat penting karenanya mempengaruhi pertumbuhan ayam pedaging.

Pakan merupakan salah satu faktor yang mempengaruhi bobot dan pertumbuhan serta organ dalam ayam pedaging. Bahan pakan yang berkualitas dan mengandung gizi tinggi relatif mahal, karena pakan konvensional masih diimpor seperti jagung dan bungkil kedelai dan penggunaannya masih bersaing dengan kebutuhan manusia. Jagung merupakan sumber energi utama bahan pakan, terutama untuk ternak monogastrik. Hal ini disebabkan kandungan energi yang dinyatakan sebagai energi metabolis (ME) relatif tinggi dibanding bahan pakan lainnya. Oleh karena itu, diperlukan upaya untuk memperoleh bahan pakan alternatif yang mudah didapat dan bernilai gizi cukup. Beberapa bahan pakan tersebut dapat berasal dari limbah hasil pertanian, seperti kulit buah kopi. Pemanfaatan limbah kulit kopi dapat dipilih sebagai salah satu alternatif bahan pakan ternak, dikarenakan limbah kulit kopi memiliki kandungan zat makanan yang hampir sama dengan jagung. Ketersediaan jumlah bahan ini di daerah-daerah yang ada di Indonesia, dan belum termanfaat dengan baik (Londra, 2007).

Mayasari (2009) mengatakan bahwa dalam kulit kopi mengandung selulosa, hemiselulosa, dan lignin. Kandungan lignin yang tinggi dalam 
limbah kulit kopi dapat menghambat proses pencernaan bagi hewan ternak. Menurut Iyayi et al. (2006), jenis serat dan sumber serat dalam ransum unggas akan berdampak pada performa dan perubahan morfologi organ dalam. Salah satu metode yang dapat digunakan untuk mengetahui kondisi organ dalam adalah dengan pengukuran berat relatif.

Untuk meningkatkan pemanfaatan dan nilai gizi dari limbah pertanian sebagai bahan pakan tersebut, maka perlu dilakukan pengolahan terlebih dahulu sebelum dijadikan pakan. Upaya yang dapat dilakukan adalah pengolahan dengan kulit kopi yaitu direndam, dijemur, dan direbus cara-cara ini merupakan teknik pengolahan yang cukup sederhana dan mudah pengolahannya bagi masyarakat. Dari pemaparan diatas maka telah dilakukan penelitian tentang pengaruh limbah kulit kopi (Coffea sp) pengolahan sederhana dengan level substitusi sebagian jagung dengan tujuan untuk mengetahui bagaimana pengaruhnya terhadap persentase organ dalam ayam pedaging

\section{MATERI DAN METODE}

PENELITIAN

\section{Lokasi Dan Waktu Penelitian}

Penelitian ini telah dilaksanakan di kandang Fakultas Peternakan Universitas Sam Ratulangi Manado pada bulan
Agustus-Oktober 2018. Waktu penelitian dilaksanakan selama 35 hari.

\section{Materi Penelitian}

Ternak yang digunakan dalam penelitian ini yaitu DOC (Day old chiken) strain CP 707 sebanyak 144 ekor tanpa membedakan jenis kelamin (unsex) dari PT. Chaeron Phokphand.

\section{Pakan}

Bahan pakan perlakuan yang digunakan dalam penelitian ini adalah kulit kopi jemur, rendam, rebus, jagung, dedak dan konsentrat.

\section{Kandang dan Peralatan}

Kandang yang digunakan dalam penelitian ini berjumlah 36 unit dan setiap unit kandang ditempati 4 ekor ayam. Tempat pakan dibuat menggunakan bambu sedangkan tempat minum menggunakan pipa berukuran 4 inchi yang dibelah menjadi dua bagian.

\section{Alat Dan Bahan}

Alat-alat yang akan digunakan dalam penelitian ini yaitu: bamboo dan botol plastic sebagai tempat pakan, timbangan digital, ember, sapu, plester, gunting, skop, cutter, sarung tangan. Sedangkan untuk bahan yang digunakan yaitu kulit kopi, dedak, konsentrat, dan 
jagung. Makanan dan air minum diberikan secara ad libitum

\section{Metode Penelitian}

Penelitian ini menggunakan rancangan Faktorial 3 x 4 dengan masingmasing perlakuan 3 ulangan (Steel and Torrie,1980). Faktor A adalah kulit kopi yang dijemur, direndam dan direbus sedangkan Faktor B adalah 4 level substitusi 0\%, 25\%, 50\%, 75\% kulit kopi terhadap jagung. Data dianalis dengan menggunakan analysis of variance (anova) apabila perlakuan menunjukan hasil yang berbeda nyata maka dilanjutkan dengan uji lanjut beda nyata jujur (BNJ)

\section{Prosedur Penelitian}

- Persiapan

Pembersihan lokasi area kandang untuk meletakan kadang yang digunakan. Kandang dibersihkan dengan menggunakan air bersih dan deterjen sebelum penataan posisi letaknya. Kandang betterai sudah dilengkapi dengan tempat pakan dan air minum yang terbuat dari bambu dan pipa air. Kandang batterai diberi label sesuai dengan perlakuan dan ulangan untuk memudahkan proses pemberian pakan perlakuan serta memudahkan proses pengambilan data. Persiapan kandang brooder untuk DOC telah dilengkapi dengan lampu 100 Watt yang berfungsi sebagai penerang dan sebagai penghangat.

- Penyediaan dan Pengolahan Kulit Kopi

Cara pengolahan kulit kopi yang sangat mudah dan sederhana yaitu diolah dengan menggunakan tiga macam pengolahan sederhana yaitu: dijemur, rendam, dan rebus. Kemudian digiling sampai menjadi tepung kulit kopi. Sebelum diberikan pakan perlakuan secara menyeluruh dilakukan pra penyesuaian (preliminary) dengan tujuan untuk mencegah terjadinya stress pada saat penggantian pakan perlakuan. pakan perlakuan diberikan pada ayam umur 15 hari sampai umur 35 hari. Komposisi zatzat nutrien dan energi metabolis bahan penyusun pakan kulit kopi, jagung, dedak, dan konsentrat dapat dilihat pada Tabel 1 dan 2. Sedangkan komposisi zat nutrien dan energi metabolis pakan perlakuan dapat dilihat pada Tabel 3 .

- Prosedur Pemotongan

Sebelum dilakukan pemotongan, ayam dipuasakan selama 12 jam dengan tetap diberi air minum. Pemotongan ternak dilakukan berdasarkan cara USDA (United State Departement Of Agriculture, 1997), yaitu dengan memotong Vena jugularis, dan Artericarotis yang terletak antara tulang kepala dengan ruas tulang leher pertama. Setelah itu ayam digantung dengan posisi kaki berada diatas, kepala 
Tabel 1. Komposisi Zat Nutrien Bahan Penyusun Pakan

\begin{tabular}{lcccccc}
\hline Bahan pakan & $\begin{array}{c}\text { Protein } \\
(\%)\end{array}$ & $\begin{array}{c}\text { EM } \\
(\mathrm{kcal} / \mathrm{kg})\end{array}$ & $\begin{array}{c}\text { SK } \\
(\%)\end{array}$ & $\begin{array}{c}\text { Lemak } \\
(\%)\end{array}$ & $\begin{array}{c}\text { Ca } \\
(\%)\end{array}$ & $\begin{array}{c}\text { P } \\
(\%)\end{array}$ \\
\hline Kulit kopi jemur* & 7,95 & 2895 & 33,6 & 1,3 & 0,21 & 1,08 \\
Kulit kopi rendam* & 10,55 & 2929 & 32,50 & 0,97 & 0,17 & 2,05 \\
Kulit kopi rebus* & 12,23 & 2764 & 20,60 & 1,28 & 0,26 & 0,88 \\
Jagung ** & 8,42 & 3182 & 2,15 & 5,17 & 0,22 & 0,6 \\
Dedak** & 12,9 & 2875 & 11,4 & 0,7 & 0,07 & 1,5 \\
Konsentrat*** & 38 & 2900 & 6 & 4 & 3 & 1,4 \\
\hline
\end{tabular}

Ket : EM= Energi Metabolis, $\mathrm{SK}=$ Serat Kasar, $\mathrm{Ca}=$ Kalsium, $\mathrm{P}=$ Fospor

*) HasilAnalisa Lab Ilmu dan Teknologi Pakan IPB

**) Timbulus et al. (2017)

***) Hasil Analisa PT. Cargil Indonesia

Tabel 2. Susunan Bahan Pakan Perlakuan

\begin{tabular}{lcccc}
\hline Bahan pakan & B0 & B1 & B2 & B3 \\
\hline Jagung & 40 & 30 & 20 & 10 \\
Kulit kopi (A1/A2/A3) & 0 & 10 & 20 & 30 \\
Konsentrat & 30 & 30 & 30 & 30 \\
Dedak & 29 & 29 & 29 & 29 \\
Mineral & 1 & 1 & 1 & 1 \\
\hline Total & 100 & 100 & 100 & 100 \\
\hline
\end{tabular}

Tabel 3. Komposisi Zat Nutrien Dan Energi Metabolis Pakan Perlakuan

\begin{tabular}{cccccccc}
\hline \multirow{2}{*}{$\begin{array}{c}\text { Faktor } \\
\text { A }\end{array}$} & Faktor B & $\begin{array}{c}\text { Protein } \\
(\%)\end{array}$ & $\begin{array}{c}\text { EM } \\
(\mathrm{kkal})\end{array}$ & $\begin{array}{c}\text { Serat kasar } \\
(\%)\end{array}$ & $\begin{array}{c}\text { Lemak } \\
(\%)\end{array}$ & $\begin{array}{c}\text { Kalsium } \\
(\%)\end{array}$ & $\begin{array}{c}\text { Fosfor } \\
(\%)\end{array}$ \\
\hline \multirow{4}{*}{ A1 } & B0 & 18,50 & 2976,55 & 5,96 & 3,47 & 1,00 & 1,09 \\
& B1 & 18,46 & 2947,85 & 9,11 & 3,08 & 1,00 & 1,14 \\
& B2 & 18,41 & 2919,15 & 12,25 & 2,69 & 1,00 & 1,19 \\
& B3 & 18,36 & 2890,45 & 15,40 & 2,31 & 1,00 & 1,23 \\
& B0 & 18,50 & 2976,55 & 5,96 & 3,47 & 1,00 & 1,09 \\
A2 & B1 & 18,72 & 2951,25 & 9,00 & 3,05 & 1,00 & 1,24 \\
& B2 & 18,93 & 2925,95 & 12,03 & 3,14 & 0,99 & 1,38 \\
& B3 & 19,99 & 2900,65 & 15,07 & 2,21 & 0,99 & 1,53 \\
& B0 & 18,50 & 2976,55 & 5,96 & 3,47 & 1,00 & 1,09 \\
A3 & B1 & 18,89 & 2934,75 & 8,02 & 3,59 & 1,01 & 1,12 \\
& B2 & 19,27 & 2892,95 & 9,65 & 2,69 & 1,01 & 1,15 \\
& B3 & 19,65 & 2851,15 & 11,50 & 2,00 & 1,02 & 1,17 \\
\hline
\end{tabular}

Keterangan: Dihitung berdasarkan tabel 1 dan 2, A1= Kulit kopi jemur A2=Kulit kopi rendam A3 $=$ Kulit kopi rebus B0 $=0 \%$ kulit kopi terhadap jagung B1= Substitusi $25 \%$ kulit kopi terhadap jagung B2= Substitusi 50\% kulit kopi terhadap jagung B3= Substitusi 75\% kulit kopi terhadap jagung 
di bawah dengan tujuan untuk mempercepat proses penitisan darah setelah ternak dipastikan mati, maka segera dicelupkan kedalam air hangat dengan suhu 50-55 ${ }^{\circ}$ Cselama 90-120 detik untuk memudahkan pencabutan bulu. Setelah bulu dicabut, proses pengeluaran jeroan dilakukan sebagai berikut:

1. Pemotongan kepala dan leher pada batas badan, sehingga saluran pernafasan dan saluran makanan ikut terpotong.

2. Pembuatan irisan diantara cloaca dan ujung tulang dada, sehingga jari-jari atau alat pengeluaran jeroan dapat masuk sampai rongga dada.

3. Pengeluaran jeroan dapat dilakukan langsung dengan tangan atau di bantu dengan alat pengeluaran jeroan.

4. Pembersihan bagian-bagian dalam rongga perut dan dada, termasuk pembuangan bagian yang tidak digunakan.

5. Untuk organ dalam yang diukur atau ditimbang dipisahkan satu per satu lalu ditimbang dengan menggunakan timbangan digital.

\section{Variabel Penelitian}

Variabel yang diukur dalam penelitian ini adalah persentase organ dalam menurut (Wiranata et al., 2013):

1. Persentase Hati

$$
\begin{aligned}
& \text { Persentase hati dengan } \\
& \text { membandingkan berat hati (g) } \\
& \text { dengan bobot hidup ayam broiler }(\mathrm{g}) \\
& \text { x } 100 \% \text {. }
\end{aligned}
$$

2. Persentase Jantung

persentase jantung dengan membandingkan berat jantung (g) dengan bobot hidup ayam broiler ( $\mathrm{g}$ ) $\mathrm{x} 100 \%$.

3. Persentase Gizzard

$$
\begin{aligned}
& \text { Persentase gizzard dengan } \\
& \text { membandingkan berat gizzard }(\mathrm{g}) \\
& \text { dengan bobot hidup ayam broiler }(\mathrm{g}) \\
& \mathrm{x} 100 \% \text {. }
\end{aligned}
$$

\section{HASIL DAN PEMBAHASAN}

Hasil penelitian persentase organ dalam ayam pedaging meliputi organ hati, jantung, dan gizzard dapat dilihat pada Tabel 4.

\section{Pengaruh Perlakuan Terhadap Persentase Organ Hati}

Hasil analisis keragaman menunjukan bahwa interaksi antara kulit kopi (A) jemur, rendam dan rebus dan level subtitusi menunjukan hasil tidak berbeda nyata $(\mathrm{P}>0,05)$ terhadap persentase hati. 
Tabel 4. Rataan Persentase Organ Dalam Organ Dalam Hati, Jantung, Gizzard

\begin{tabular}{|c|c|c|c|c|c|}
\hline \multirow[b]{2}{*}{ Variabel } & \multicolumn{4}{|c|}{ Perlakuan } & \multirow[b]{2}{*}{ Rataan } \\
\hline & $\begin{array}{c}\text { Level } \\
\text { subtitusi }\end{array}$ & A1 & $\mathrm{A} 2$ & A3 & \\
\hline \multirow{4}{*}{ Persentase Hati (\%) } & B0 & $1,38 \pm 0,04$ & $1,38 \pm 0,04$ & $1,38 \pm 0,04$ & $1,38 \pm 0,00^{a}$ \\
\hline & B1 & $1,34 \pm 1,14$ & $1,57 \pm 0,27$ & $1,62 \pm 0,18$ & $1,51 \pm 0,15^{a}$ \\
\hline & B2 & $1,38 \pm 0,22$ & $1,70 \pm 0,25$ & $1,68 \pm 0,19$ & $1,72 \pm 0,06^{\mathrm{ab}}$ \\
\hline & B3 & $2,10 \pm 0,37$ & $1,68 \pm 0,13$ & $1,79 \pm 0,26$ & $1,86 \pm 0,22^{b}$ \\
\hline \multirow[t]{2}{*}{ Rerata } & & $1,65 \pm 0,36$ & $\mathbf{1 , 5 8 \pm 0 , 1 5}$ & $1,62 \pm 0,18$ & \\
\hline & B0 & $0,72 \pm 0,07$ & $0,72 \pm 0,07$ & $0,72 \pm 0,07$ & $0,72 \pm 0,00$ \\
\hline \multirow{3}{*}{ Persentase Jantung (\%) } & B1 & $0,36 \pm 0,22$ & $0,36 \pm 0,26$ & $0,31 \pm 0,26$ & $0,34 \pm 0,03$ \\
\hline & B2 & $0,35 \pm 0,22$ & $0,40 \pm 0,24$ & $0,36 \pm 0,03$ & $0,37 \pm 0,02$ \\
\hline & B3 & $0,42 \pm 0,08$ & $0,29 \pm 0,60$ & $0,45 \pm 0,22$ & $0,39 \pm 0,09$ \\
\hline \multirow{2}{*}{ Rerata } & & $0,47 \pm 0,21$ & $0,44 \pm 0,20$ & $0,46 \pm 0,23$ & \\
\hline & $\mathrm{B} 0$ & $1,73 \pm 0,60$ & $1,73 \pm 0,60$ & $1,73 \pm 0,60$ & $1,73 \pm 0,00$ \\
\hline \multirow[t]{3}{*}{ Persentase Gizzard (\%) } & B1 & $1,60 \pm 0,02$ & $1,85 \pm 0,01$ & $1,83 \pm 0,06$ & $1,76 \pm 0,14$ \\
\hline & $\mathrm{B} 2$ & $2,13 \pm 0,04$ & $2,22 \pm 0,07$ & $2,40 \pm 0,05$ & $2,25 \pm 0,13$ \\
\hline & B3 & $2,77 \pm 0,18$ & $2,36 \pm 0,02$ & $2,32 \pm 0,13$ & $2,48 \pm 0,24$ \\
\hline Rerata & & $2,06 \pm 0,53$ & $2,04 \pm 0,30$ & $2,07 \pm 0,34$ & \\
\hline
\end{tabular}

Keterangan: Superskrip yang berbeda pada kolom yang sama menunjukan berbeda nyata $(\mathrm{P}<0,05)$

Hasil yang sama juga ditunjukan oleh metode pengolahan kulit kopi (A) terhadap persentase hati, hal ini menunjukan bahwa kulit kopi jemur, rendam dan rebus tidak memberikan pengaruh. Hasil yang berbeda ditunjukan oleh perlakuan level substitusi (B) memberikan pengaruh yang berbeda nyata $(\mathrm{P}<0,05)$ terhadap persentase hati. Berdasarkan uji lanjut BNJ level subtitusi (B) menunjukan bahwa B3 berbeda nyata $(\mathrm{P}<0.05)$ dengan B0 dan B1, sedangkan B2 berbeda nyata $(\mathrm{P}<0.05)$ dengan $\mathrm{B} 0$ dan tidak berbeda nyata $(\mathrm{P}>0.05)$ dengan $\mathrm{B} 1$, serta memberikan pengaruh tidak berbeda nyata $(\mathrm{P}>0.05)$ dengan B3. Perlakuan B1 memberikan pengaruh tidak berbeda nyata dengan B0 $(\mathrm{P}>0.05)$. Rataan terendah terdapat pada B0 yaitu pakan kontrol sebesar $1,38 \%$, sedangkan persentase tertinggi terdapat pada B3 yaitu pakan perlakuan level substitusi $75 \%$ dengan rataan sebesar $1,86 \%$. Menurut Has et al. (2014) bahwa persentase hati ayam broiler berada pada kisaran normal yaitu $2,13 \%$ 2,38\% dari bobot hidup.

Perbedaan ukuran persentase hati pada ransum perlakuan dapat dilihat jelas dari hasil data bahwa semakin tinggi serat kasar maka ukuran hati akan semakin besar pula. Ini disebabkan karena faktor pemberian pakan yang mengandung serat kasar tinggi dapat meningkatkan kemampuan metabolisme ayam sehingga mengakibatkan pembesaran pada ukuran 
hati ayam. Peningkatkan ukuran hati dapat terjadi karena ransum serat kasar dapat meningkatkan kemampuan metabolisme unggas untuk mencerna serat kasar (Hetland et al., 2005). Kandungan serat kasar dapat berpengaruh pada jumlah energi yang dihasilkan, semakin tinggi kandungan serat pada ransum maka semakin banyak energi yang dipakai untuk mencerna. Hal ini sejalan dengan pendapat (Nurdiyanto et al., 2015) menjelaskan bahwa semakin tinggi kandungan serat pada ransum, semakin tinggi energi yang dipakai untuk mencerna serat tersebut. Menurut (Whittow, 2002) besar dan berat hati dipengaruhi oleh beberapa faktor seperti jenis hewan, besar tubuh, genetik serta pakan yang diberikan seperti halnya jantung, hati juga dipengaruhi oleh tingginya kandungan protein dan $\mathrm{NaCl}$ pada pakan.

\section{Pengaruh Perlakuan Persentase Organ Jantung}

Terhadap

Hasil analisis keragaman menunjukan bahwa interaksi antara kulit kopi (A) jemur, rendam rebus dan level substitusi menunjukan hasil tidak berbeda nyata $(\mathrm{P}>0.05)$ terhadap persentase jantung. Kisaran persentase jantung pada penelitian ini seperti tercantum pada Tabel 4 yaitu 0,29\%-0,72\% dari bobot karkas, hal ini tidak jauh berbeda dengan pendapat (Swito et al., 2015) persentase jantung ayam pedaging sekitar $0,43-0,54 \%$ dari bobot hidup. Pemberian ransum menggunakan limbah kulit kopi tidak terlalu membawa dampak pada besar ukuran jantung bahkan juga terjadi penurunan persentase bergantung pada level pemberian kulit kopi. Menurut (Aqsa et al., 2016) ukuran jantung sangat dipengaruhi oleh jenis, umur, besar dan aktivitas hewan. Peningkatan kemampuan metabolism untuk mencerna serat kasar yang terkandung pada ransum sangat berpengaruh pada pembesaran jantung. (Hetland et al., 2005) Pembesaran ukuran jantung biasanya disebabkan oleh adanya penambahan jaringan otot jantung. Dinding jantung mengalami penebalan sedangkan ventrikel relative menyempit apabila otot menyesuaikan diri pada kontraksi yang berlebihan. Pembesaran jantung dapat terjadi karena adanya akumulasi racun pada otot jantung. Jantung yang terinfeksi penyakit maupun racun biasanya akan mengalami perubahan ukuran.

\section{Pengaruh Perlakuan Terhadap Persentase organ dalam gizzard}

Hasil analisis keragaman menunjukan bahwa interaksi antara kulit kopi (A) jemur, rendam, dan rebus serta level subtitusi menunjukan hasil tidak berbeda nyata $(\mathrm{P}>0,05)$ terhadap persentase gizzard. Data hasil penelitian pada Tabel 4 
dapat dilihat bahwa penggunaan kulit kopi menghasilkan kisaran gizzard lebih tinggi yaitu 1,60\%-2,77\% dari bobot karkas. Sedangkan menurut Ukim et al. (2012) menyatakan bahwa secara umum persentase bobot gizzard ayam broiler berkisar antara 2,07-2,31\% dari bobot hidup. Menurut Hetland et al. (2005) serat kasar pakan dan tekstur menjadi faktor yang penting mempengaruhi bobot gizzard. Tingginya kandungan serat kasar dalam pakan perlakuan dalam penelitian ini menyebabkan terjadinya peningkatan drastis pada gizzard. Serat yang tinggi dalam pakan akan memperbesar ukuran gizzard karena organ tersebut dipacu untuk lebih banyak bekerja secara fisiologis dalam memproses pencernaan serat baik secara mekanik maupun enzimatik.

\section{KESIMPULAN}

Hasil penelitian ini dapat disimpulkan bahwa penggunaan tepung limbah kulit kopi pada semua metode pengolahan jemur, rendam, rebus yang terbaik hanya sampai pada $25 \%$ menggantikan sebagian jagung terhadap persentase organ dalam ayam pedaging.

\section{DAFTAR PUSTAKA}

Aqsa, A. D., Khaerani Kiramang dan M. Nur Hidayat. 2016. Profil organ dalam ayam pedaging (broiler) yang diberi tepung daun sirih (Piper Betle Linn) sebagai imbuhan pakan. Jurnal Ilmu dan Industri Peternakan 3(1): 148-159

Has, H., Astriana Napirah dan Amiluddin Indi. 2014. Efek peningkatan serat kasar dengan penggunaan daun murbei dalam ransum broiler terhadap persentase bobot saluran pencernaan. Jurnal Ilmu dan Teknologi Peternakan Tropis 1(1): 63-69

Hetland, H., B. Svihus, dan M. Choctt. 2005. Role of activity in layers. J. Apply. Poultry Res. 14:38-46.

Iyayi, E., H. Kluth, dan M. Rodehudscord. 2006. precaecal crude protein digestibility, organs relative weight and performance in broilers fed diets containing enterolobium cyclocarpum and mucuna pruriens seed flour in place of soybean mean. Arch. Geflugelkunde 70(4): 161167

Londra, M. 2007. Potensi pemanfaatan limbah kopi untuk pakan penggemukan kambing peranakan etawah. Jurnal Balai Pengkajian Teknologi Pertanian 28(5): 536542.

Mayasari, N. 2009. Pengaruh Penambahan Kulit Buah Kopi Robusta (coffea canephora) Produk Fermentasi Jamur Tiram putih (Pleurotus ostreatus) Dalam Ransum Terhadap Konsentrasi VFH dan NH3 (In Vitro). Bandung: KPP Ilmu Hayati. LPPM ITB.

Nurdiyanto, R., Rudy Sutrisna dan Khaira Nova. 2015. Pengaruh ransum dengan persentase serat kasar yang 
berbeda terhadap performa ayam jantan tipe medium umur 3-8 minggu. Jurnal Ilmiah Peternakan Terpadu 3(2): 12-19.

Steel, R. G. D. and J. H. Torrie. 1980. Principles and Procedures of Statistics A Biometrical Approach. Second Edition. Mc Graw-Hill International Book Company. Tokyo. Page 633.

Swito., D. Sudrajat dan R. Handarini. 2015. Substitusi jagung dan ampas kurma dalam ransum komersial terhadap persentase giblet dan lemak abdomen ayam pedaging. Jurnal Peternakan Nusantara 1(1):25-32.

Timbulus, C.M., P. R. R. I. Montong, A. Dp. Mirah, S. E. Siswosubroto. 2017. Penampilan produksi ternak babi grower yang menggunakan tepung kulit kopi sebagai bahan pengganti sebagian dedak halus pada pakan. Jurnal Zootek 37(2):242-251

Ukim, C. I., G.S. Ojewole dan C.O. Obun, E.N. $\quad 2012$. Performans and carcass and organ weights of broiler chicks fed graded levels of acha grains (Digitaria exils). Journal of Agriculture and Veterinary Science 1(2): 28-33

USDA. 1997. Poultry Grading Manual. Agriculture Hand Book No. 30. U.S Department of Agriculture.

Wiranata, G.A., I G. A. M. K. Dewi, dan R. R. Indrawati. 2013. Pengaruh energi metabolis dan protein ransum terhadap persentase karkas dan organ dalam ayam kampong (Gallus domesticus) Betina Umur 30 Minggu. Jurnal Peternakan Tropika 1(2):87-100.
Whittow. G. 2002. Sturkies Avian Phsycology. $5^{\text {th }}$. Akademik Pres. USA. 